remembrance of things past or the substance of things hoped for. Readers who prefer to treat "apocalypse" as a historically-conditioned phenomenon will have to account for the resistance to teleological futurity that Netzley identifies in Milton's and Marvell's lyric poems by other means.

The implications of Netzley's argument about the lyric poems are intriguing both for reading other works by Milton and Marvell and for early modern literary studies generally. How does Milton's and Marvell's "lyric apocalypse" relate to the millenarian tendencies or political projects of their prose? How might Netzley's reading of the lyric poems generate fresh readings of Paradise Lost or "Last Instructions to a Painter"? Do other lyrical poets of the period treat political events in a similarly a-teleological way? What is the relationship between historical context, aesthetic categories, and a philosophical construct such as "apocalypse"? In presenting Milton and Marvell as acting on an apocalyptic impulse, which differs from traditional interpretations of their lyric poems, Netzley is suggesting new ways by which they can liberate readers from the tyranny of outcome-based reading with only a view to the future.

BEN FABER

Redeemer University College

\title{
Nicholson, Catherine.
}

Uncommon Tongues: Eloquence and Eccentricity in the English Renaissance. Philadelphia: University of Pennsylvania Press, 2014. Pp. 215. ISBN 978-08122-4558-5 (hardcover) \$55.

Catherine Nicholson's study of the vernacular in early modern England, Uncommon Tongues, is a triumph: winsome and elegant prose, broad erudition, and an abiding attention to her central argument-that with dubious success a "barbarous" nation sought to import and imbibe old wine in new bottles, accommodating classical to native thought. Nicholson's remit is the "failed experiment" of late sixteenth-century English eloquence-“failed" from later perspectives, like Samuel Johnson's-as it marked not only nationhood but "the outer limits of vernacular decorum" (164-65). English writers found in the "fantasy" of eloquence "a potent justification for their efforts on behalf of the vernacular": in ornament was armament; eloquence as an antidote to 
"errancy" might build "a stronger and more cohesive England" (2). But within this remedy lay the problem of unfamiliarity, the necessity of using "outlandish" words from foreign languages to describe the structures, figures, and effects of the vernacular-as one can see readily in George Puttenham's at times bizarre terms for figures of speech and thought (epizeuxis, for example, he calls "cuckoospell"). As Nicholson notes, there is "tension between insularity and externality in sixteenth-century debates about eloquence," determined, in part, by "the residue of the immersion in the classical tradition" and its "unresolved attitude toward linguistic difference" (10-11). What interests her is the "disabling" pressure exerted by antiquity on the theory and practice of vernacular eloquence as classical traditions were "domesticated" (11-12), as "strangeness" of both lexis and figure was "both the antithesis and the epitome of style" (4). This paradox fuels early modern inquiry, as the "vernacular's literary potential [...] intersected with, reflected, and informed more widespread debates about England's place in the world-historically marginal, newly insular, increasingly mobile, and uncertainly bounded" (9).

In chapter 1, Nicholson explores English humanist pedagogy and its focus on English as "a language constituted and regenerated by its difference and distance from the classical tongues" (21); eloquence itself is transformed in the "self-conscious reflections" of scholars like Thomas Elyot and Roger Ascham. From the "strain of moving between tongues" (Latin and English) emerges "a more positive sense of what distance and difficulty might mean for English vernacular culture and language" (22). In Nicholson's reading of Richard Mulcaster, "English may partake freely of all other linguistic models while retaining a strong sense of its own local virtues" (42).

Sixteenth-century English rhetoricians faced a dilemma: as they redescribed and domesticated rhetorical canons, they found in the vernacular "a medium of transfiguration and transport-most potently attractive when it is most conspicuously far-fetched." Style "reorients" rhetoric, Nicholson argues in chapter 2, "transforming its defining investments in commodity and commonality into a fascination with exoticism and excess" (48-49). Classical topoi are shaped by "local deliberation," by "the orator's knowledge of actual locales, for plausibility is contingent upon time, place, and persons" (55). For example, Thomas Wilson's 1553 Arte of Rhetorique synthesizes "classical ideals and local anecdotes" (57). While figures circulated as local currency, writers of various sorts admired the marvellous, the foreign, the strange. "Foreignness" 
had been lauded since Aristotle, but was "seemingly at odds with his insistence that rhetorical style not violate the norms of clarity and common usage" (61). The ingress is metaphor. Ornamentation and abuse are consanguine, and that intimacy produces, from antiquity on, "constant anxiety" as well as taxonomies-Attic, Asiatic, Rhodian-familiar to historians of rhetoric (62-64). Such anxiety both "impeded and abetted" the translation of classical conceptions of rhetoric into English. England was marked by its distance from Greece and Rome, its barbarity, but "the ancient geography of eloquence proved surprisingly amenable to the incursions of outsiders" (70).

John Lyly offers one such incursion, about which Nicholson, in chapter 3, is engaging: Euphues is "an ironic and insightful critique of the English pursuit of eloquence," embodying the "tension between the virtues of home and the appeal of the far-fetched" $(73,76)$. She treats travel and "commonplacing" as means of distributing rhetorical wealth, noting that "the analogy between global exploration and the labor of reading and writing functions as a kind of metacommonplace of sixteenth-century humanism" (83); as a way of transcending geographical and temporal distance (85). Euphues intervenes by critiquing the hazards of "the endless iterability of the commonplace" and turning stories of geographical errancy into "a far more complicated meditation on the waywardness of rhetoric itself" $(89,87)$. Euphues tests as much as it embodies humanist habits of thought.

Chapter 4 treats poetry and place in Spenser, who refines the "mother tongue" by testing the limits of the pastoral (101-03). Arguing that the paratexts and apparatuses invite readers to apprehend the Shepheardes Calendar as they would scripture and its commentaries, Nicholson insists on corresponding rises in both "estimation" and "anxiety" about the vernacular. Spenser offers an unlikely resolution in "refusing to admit an opposition between familiarity and strangeness," in performing a "rereading" of literary exile (107-09). The "disinclination" to sing on the part of Spenser's shepherds offers "alienation," for which Ovid is the archetype, as the enabling conditions of native eloquence (112-13). A "truly English poetics" appears in E. K.'s notes, which "habitually conflate foreignness with familiarity and estrangement with identification" (122).

English poetics defined itself against a bombastic other: as poets applied classical prosody to English, translating quantities to "accents," they set themselves apart, in rhetorical terms, from the Asiatic, here epitomized by 
Christopher Marlowe's Tamburlaine, which "foregrounds various anxietiesbarbarity and cultural degeneracy, tyranny and lameness - that plagued figures such as Ascham, Spenser, and Harvey in their efforts to rehabilitate English quantitative measure" (129). English verse is revivified by "its disregard from the decorums of more civilized tongues," its lack of quantitative feet a sign of abundance (130-32). In this context, Nicholson examines Puttenham's patternpoems, Marlowe's play, and the notion that, for sixteenth-century England, "eloquence offers a bloodless path to imperial might" (146). Focused on Samuel Daniel's Defense of Ryme (1603), Nicholson re-reads the history of eloquence, its civilising influences, in order to make space for the "barbarian": tracing the career of the "strutting Scythian" and his literary and political conquests offers "a more expansive and elastic version" of literary history; "it is thanks to Tamburlaine that the Renaissance happened at all" (158-59).

Nicholson is an attentive, robust writer, but she has a persistent stylistic tic. Phrases like "appealing to and resisting" - there are dozens of examplescheapen otherwise careful, supple thinking, as Nicholson sometimes presses contemporary affection for paradox into extended service. Oddly, too, even though she examines work that "redefines eloquence [...] in terms of elocution" (47-48), and treats some of Gabriel Harvey's work, Nicholson nowhere mentions Petrus Ramus, the Ramist controversies at Cambridge, or his influence in denuding rhetorical inquiry. These are cavils: Uncommon Tongues is an exceptionally strong contribution to studies of the vernacular in early modern Europe.

STEPHEN PENDER

University of Windsor

\section{Ovid.}

Ovid in English, 1480-1625. Part 1. Metamorphoses. Ed. Sarah Annes Brown and Andrew Taylor.

MHRA Tudor \& Stuart Translations 4 (1). London: Modern Humanities Research Association, 2013. Pp. $238+17$ ill. ISBN 978-0-947623-92-0 (hardcover) \$44.99.

The aim of the MHRA's series of Tudor \& Stuart Translations is to republish key early modern translations into English of works in other European languages 